\title{
Retrospective Analysis of Peripheral T-Cell Lymphoma Patients: Single Center 'Real-Life' Experience
}

\section{Çevresel T-Hücreli Lenfoma Hastalarının Geriye Dönük Değerlendirmesi: Tek Merkez 'Gerçek-Yaşam' Deneyimi}

\author{
Murat Ozbalak $^{1 \oplus}$, Metban Mastanzade ${ }^{1 \oplus}$, Ozden Ozluk $^{1 \oplus}$, Tarık Onur Tiryaki ${ }^{1 \oplus}$, Ipek Yonal Hindilerden ${ }^{1 \oplus}$ \\ Mustafa Nuri Yenerel ${ }^{1}$, Ali Yılmaz Altay ${ }^{\circledR}$, Gulcin Yegen ${ }^{\circledR}$, Ibrahim Oner Dogan ${ }^{\circledR}$, Meliha Nalcaci ${ }^{1 \oplus}$ \\ Sevgi Kalayoglu Besisik ${ }^{1}$ (1)
}

${ }^{1}$ Istanbul University Istanbul Medical Faculty, Department of Internal Medicine, Division of Hematology, Istanbul, Turkey ${ }^{2}$ Istanbul University Istanbul Medical Faculty, Department of Pathology, Division of Hematopathology, Istanbul, Turkey

${ }^{3}$ Koç University Medical Faculty, Department of Pathology, Division of Hematopathology, Istanbul, Turkey

Received: 22.09.2020 / Accepted: 21.10.2020 / Published Online: 29.12.2020

Cite as: Ozbalak M, Mastanzade M, Ozluk O, Tiryaki TO, Yonal Hindilerden I, Yenerel MN, Altay AY et al. Retrospective analysis of peripheral T-cell lymphoma patients: Single center 'real-life' experience. Med J Bakirkoy 2020;16(4):392-8.

\section{ABSTRACT}

Objective: Peripheral T-cell lymhomas (PTCLS) represent a heterogeous group of diseases, with poor long-term outcomes excluding ALK+ anaplastic large cell lymphoma (ALCL).

Method: We represent data of our retrospective analysis of 62 consecutive PTCL cases diagnosed since 2002. Median observation time was 16 months.

Results: The overall response rate to first line treatment was 53 percent. Data related to median progression- free survival and overall survival times could not be obtained for $A L K+A L C L$ group whereas median progression-free survival and overall survival times for $A L K$-negative $A L C L$ group were 1 and 18 months, respectively. Disease progression was frequently observed histologically in ALK-negative group. For ALKnegative $A L C L$, advanced stage disease was defined as the presence of serum albumin $<3.4 \mathrm{~g} / \mathrm{dl}$, serum total protein $\leq 6.2 \mathrm{~g} / \mathrm{dl}$, high serum $L D H$, and serum ferritin $>200 \mathrm{ng} / \mathrm{ml}$, presence of B symptoms, and extranodal involvement of more than one site. Risk factors associated with death were serum albumin $<3.4 \mathrm{~g} / \mathrm{dl}$, serum total protein $\leq 6.2 \mathrm{~g} / \mathrm{dl}$, serum ferritin over $200 \mathrm{ng} / \mathrm{ml}$, and bone marrow involvement at the time of diagnosis. During follow-up 39 patients (64\%) died. Most common reasons were progressive disease and infections. Four patients developed secondary malignancies.

Conclusion: Our study is a reflection of the 'real-life'. Three patients died due to disease progression shortly after diagnosis without providing treatment due to aggressiveness of the disease. Alternatives to CHOP-based chemotherapies should be found for the ALK + non-anaplastic large cell lymphoma group.

Keywords: $T$ cell lymphoma, Anaplastic lymphoma kinase, ALK positive, ALK negative

Öz

Amaç: Çevresel T hücreli lenfomalar heterojen bir hastalık grubu olup, ALK+ anaplastik büyük hücreli lenfoma dışında uzun dönem sonuçları kötüdür.

Yöntem: Merkezimizde 2002 senesinden beri tanı alıp takip olmuş 62 ardışık çevresel T hücreli lenfoma hastamızın verilerini sunmaktayız. Ortanca takip süremiz 16 aydır.

Bulgular: ilk seri tedaviye genel yanıt oranı \%53'dür. Ortanca progresyonsuz ve genel sağkalım sürelerine ALK+ anaplastik büyük hücreli lenfoma grubunda ulaşılamamıştır. ALK negative grupta ise ortanca progresyonsuz ve genel sağkalım süreleri sırasıyla 1 ve 18 ay olarak tespit edilmiştir. Hastalık progresyonu sıklıkla histolojik olarak ALK negatif grupta gözlenmiştir. ALK negative anaplastik büyük hücreli lenfomada ileri evre hastalık, serum albumin $<3,4 \mathrm{~g} / \mathrm{dl}$, serum total protein $\leq 6.2 \mathrm{~g} / \mathrm{dl}$, serum ferritin $>200 \mathrm{ng} / \mathrm{ml}$ olması, yüksek serum $L D H$ düzeyi, $B$ semptomları olması ve birden fazla ekstranodal tutulum bölgesi olması, progresyonla iliškili risk faktörleri olarak tanımlanmıștır. Ölüm ile ilişkili risk faktörleri ise serum albumin $<3.4 \mathrm{~g} / \mathrm{dl}$, serum total protein $\leq 6.2 \mathrm{~g} / \mathrm{dl}$, serum ferritin $>200 \mathrm{ng} / \mathrm{ml}$ ve tanı anında kemik iliğinin tutulu olması olarak belirlenmiștir. Takipte 39 hasta (\%64) vefat etmiştir. En sık neden ise hastalığın ilerlemesi ve enfeksiyonlardır. Dört hastada ise ikincil malinite gelişmiştir.

Sonuç: Çalıșmamıș, 'gerçek yaşam'ın bir yansımasıdır. Üç hasta, tanıdan kısa süre sonra tedavi dahi verilemeden, hastalığın agresifliği neticesinde kaybedilmiştir. ALK+ anaplastik büyük hücreli lenfoma dışı grupta CHOP tabanlı kemoterapilere alternatif bulunması gereklidir.

Anahtar kelimeler: $T$ hücreli lenfoma, anaplastik lenfoma kinaz, ALK pozitif, ALK negatif

\begin{tabular}{|c|c|c|c|}
\hline Corresponding Author: & M. Ozbalak 0000-0002-3040-4052 & I. Yonal Hindilerden 0000-0003-3020-850X & I.O. Dogan 0000-0003-1996-6983 \\
\hline \multirow{3}{*}{ sevgi.kalayoglu@istanbul.edu.tr } & M. Mastanzade $0000-0002-2281-5978$ & M.N. Yenerel 0000-0002-6473-1342 & M. Nalcaci 0000-0002-2555-5024 \\
\hline & O. Ozluk 0000-0003-3667-3496 & A.Y. Altay 0000-0003-4678-2047 & S. Kalayoğlu Besisik 0000-0002-9310-1278 \\
\hline & T.O. Tiryaki 0000-0002-0096-5684 & G. Yegen 0000-0003-2497-219X & \\
\hline
\end{tabular}




\section{INTRODUCTION}

Peripheral T-cell lymphomas (PTCLs) represent a heterogeneous group of lymphoproliferative disorders derived from mature T cells and usually characterized by an aggressive clinical course. Although their incidence rates vary according to geographic location and ethnic origin of the population PTCLs are uncommon in general which contributes to limited experience bringing several challenges in diagnosis and also standardization of treatment ${ }^{(1)}$. These neoplasms can be grouped according to their usual presentation into disseminated diseases (leukaemias), predominantly extra-nodal or cutaneous, or predominantly nodal lymphomas.

Multiple subtypes represent distinct clinicopathologic entities or prognoses. The most common subtype is PTCL-not otherwise specified (PTCL-NOS-26\%), followed by angiommunoblastic TCL (AITCL-19\%), Anaplastic Lymphoma Kinase (ALK) -positive anaplastic large cell lymphoma (ALCL) (7\%), ALK -negative ALCL (6\%) and, enteropathy- associated TCL (EATCL- $<5 \%)^{(2)}$. CHOP-type chemotherapy has been the mainstay of therapy. However they have poor outcomes with a 3 -year survival rate of approximately $30 \%$ with the notable exception of ALK-positive ALCL. Compared to ALK- negative PTCLs, ALK- positive group was reported to have better 5 -year failure- free survival (FFS) $60 \%$ vs $36 \%, p=0.015)$ and OS (70\% vs $46 \%, p=0.016)$. The survival rates were worse than ALK- negative ALCL for PTCL-NOS and AITCL ${ }^{(3)}$. Although addition of etoposide to $\mathrm{CHOP}$ regimen was associated with increased response rates and better PFS, it had no contribution to OS ${ }^{(4)}$. Additionally, no clear survival advantage of consolidative autologous hematopoietic stem cell transplantation (HSCT) could be shown ${ }^{(5)}$.

The parameters such as advanced age, increased serum LDH levels, poor performance status, extranodal disease, decreased platelet counts, increased Ki67 score and many other serum biomarkers were analyzed to estimate the survival of PTCL patients and to refine the poor prognostic group. The International Prognostic Index (IPI) ${ }^{(6)}$, the prognostic index for PTCL-NOS (7), prognostic index of International T Cell Lymphoma Project ${ }^{(8)}$, the T cell score ${ }^{(9)}$ and NCCN-IPI ${ }^{(10)}$ are used to stratify prognostic risk parameters and estimate survival. Gene expression profile studies showed that DUSP-22 rearranged ALK- negative ALCL patients have
OS rates similar to ALK positive ALCL patients (11). Additionally, high expression of GATA3 in PTCL-NOS was significantly associated with worse OS ${ }^{(12)}$.

For relapsed/refractory PTCL patients the second- line treatment may consists of single agents brentuximab vedotin for CD30 positive disease, pralatrexate ${ }^{(13)}$, lenalidomide ${ }^{(14)}$, romidepsin ${ }^{(15)}$, belinostat ${ }^{(16)}$ or combination regimen with intention to proceed to autologous ${ }^{(17)}$ or allogeneic ${ }^{(18)}$ HSCT. However, the optimal recommendation could not be defined.

Herein, we report our single center data for PTCL patients. We hope documentation center's experience with survival data related to this rare disorder group with a poor outcome in general may provide guidance for novel therapy replacing traditional strategies.

\section{MATERIAL and METHODS}

From 2002 to 2019, patients diagnosed with PTCL and managed at our institution were retrospectively analyzed. Primary cutaneous T- cell lymphomas and nasal $\mathrm{NK} / \mathrm{T}$-cell lymphomas were not included in the analysis.

All pathology specimens were assessed by our pathology department. The stratification of cases was made according to 2008 World Health Organization classification of lymphoid neoplasms ${ }^{(19)}$.

The evaluation of treatment response was realized with $\mathrm{CT}$ or PET/CT. OS was defined as the time from initial diagnosis to death or latest follow-up. PFS was defined as the time from initial diagnosis to progression or relapse or death due to progressive disease.

Our study was approved by Istanbul University Istanbul Medical Faculty ethics committee (2019/1044), and conducted according to the principles of Declaration of Helsinki.

\section{Statistical Analysis}

Categorical variables were compared using Pearson's chi- square test. Multivariate analysis was done using a stepwise Cox proportional hazard model. The survival estimates were calculated with Kaplan-Meier method. STATA/SE11.1 was used for the statistical analysis. 


\section{RESULTS}

\section{Population characteristics}

There were 62 eligible patients. The median age was 54 years (range 20-82). Although not statistically significant, ALK+ ALCL patients were younger with a median age of 32 years, compared to the rest of the cohort having a median age of 55 years. Seventy-four percent of the patients was male. The patients were distributed according to the histological type of the disease as follows: PTCL-NOS ( $n=17: 27 \%)$, AITL ( $n=13: 21 \%), A L C L$ $(n=21: 34 \%), \operatorname{HSTCL}(n=4)$, EATCL $(n=4)$ and NK/T cell lymphoma $(n=3)$. Among 21 ALCL patients, 9 were ALKpositive. Forty-three patients presented with advanced stage disease (Ann-Arbor stage III-IV). Most commonly involved extranodal sites were bone marrow, spleen, liver and gastrointestinal tract. Patient characteristics are summarized in Table 1 . The median follow-up time was 16 months (range:1-156).

\section{Survival Analysis Of The Entire Cohort}

The median PFS and OS rates were 8 months $(95 \% \mathrm{Cl}$ :

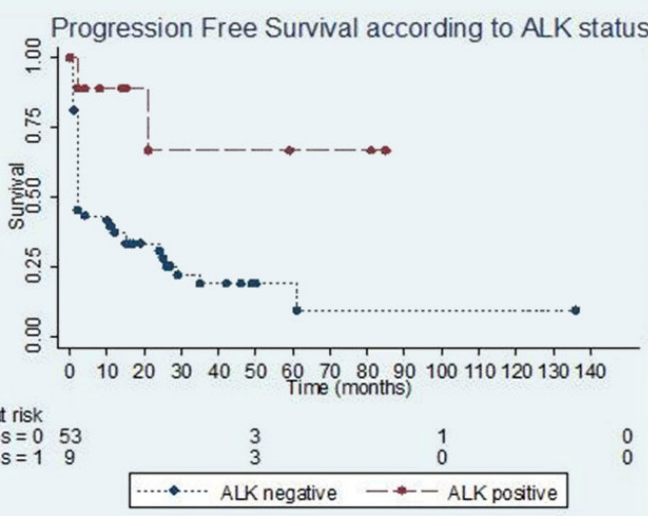

A

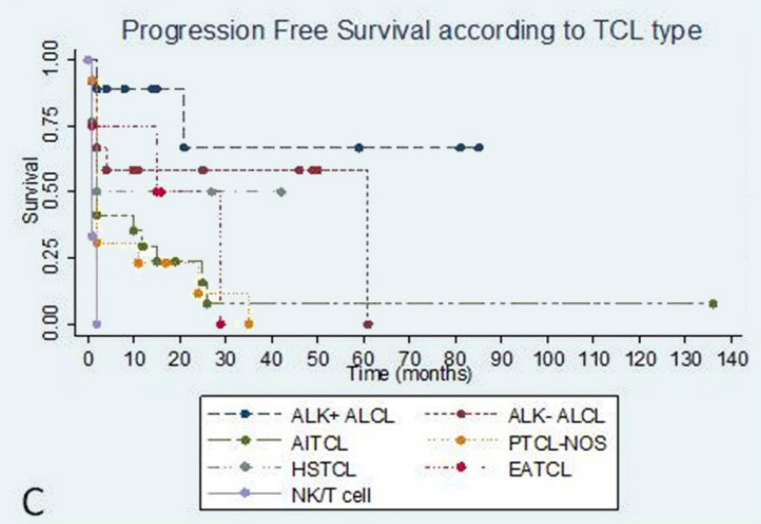

0.37-0.61) and 20 (95\% Cl: 0.36-0.61) months for the entire cohort, respectively. Five-year PFS rates was $19 \%$ (95\% Cl: 0.07-0.35) whereas OS rate was $26 \%$ (95\% Cl: 0.14-0.39).

The ALK+ ALCL patients had significantly better survival rates compared to the rest of the cohort. The data for the median PFS and OS were not reached for ALK+ALCL group though they were less than 2 ( $95 \% \mathrm{Cl}$ : 0.33-0.60) and 18 (95\% Cl: $0.35-0.62)$ months for the rest of the cohort, respectively.

Five-year PFS rates were $66 \%$ (95\% Cl: 0.16-0.91) for ALK+ALCL whereas $19 \%$ (95\% Cl: 0.09-0.32) for nonALK+ groups. Five -year OS rates were $75 \%(95 \% \mathrm{Cl}$ : 0.31-0.93) for ALK+ALCL group and 18\% (95\% Cl: 0.070.32 ) for the rest of the cohort. The survival curves according to histology are presented in Figure 1.

\section{Treatment Strategy}

Three patients (1 PTCL-NOS, 1 EATCL, 1 NK/T cell lymphoma) died without having chance to be treated, due
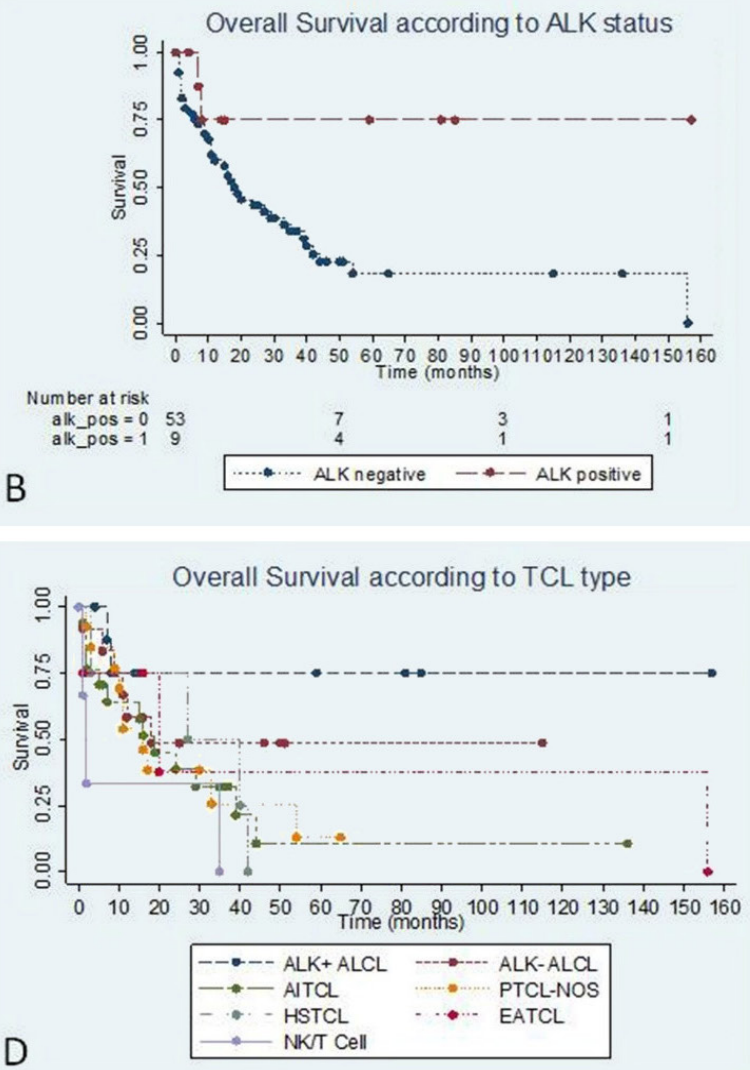

Figure 1. Kaplan-Meier Survival Curves - Progression free survival and overall-survival according to ALK status (A\&B) and T cell lymphoma type (C\&D) 
to rapid progression of the disease. One patient with HSTCL underwent splenectomy which established the diagnosis and the patient received steroid treatment. One patient with PTCL-NOS had a poor ECOG performance status and could only be given steroids.

The remaining 56 patients received mainly $(n=46)$. CHOP-based chemotherapy. One patient initially was diagnosed as having $H L$ and received $A B V D$ as first- line treatment . Re-evaluation of the case revealed the diagnosis of PTCL-NOS. In five patients, radiotherapy was added to the treatment.

The ORR to first line treatment was $52 \%$, including CR in $23(40 \%)$ and PRs in 7 (12\%) cases.

Regardless of the treatment arm, the CR rate was significantly higher in ALK+ALCL than in other groups (77\% of the patients achieved CR). The ORR was $67 \%$ for ALKALCL, whereas it was lower for PTCL-NOS (47\%) and AITCL (31\%) groups (Table 1)

As treatment for relapsed and refractory patients the treatment agent was chosen taking into account the toxicity of previous treatment and patients' performance status. Gemcitabine- based regimens, brentuximab vedotin (BV), bendamustine, pralatrexate and lenalidomide were the preferred regimens for further treatment of these cases.

\section{Survival Analysis of Patients Who Had Objective Response to Initial Treatment}

Median PFS and OS for responders to the first- line treatment were 29 (95\% Cl: 0.31-0.73) and 136 months, respectively. The 5-year OS (52\%: $95 \% \mathrm{Cl}$ : 0.29-0.71) and PFS rates (48\%: $95 \% \mathrm{Cl}: 0.25-0.68)$ were as indicated.

\section{Patients Who Had SCT}

Among 30 responders to the first- line treatment, 10 patients underwent autologous SCT upfront as consolidation. For this group 5-year OS (75\% :95\% Cl: 0.31 $0.93)$ and PFS rates (63\%:95\% Cl: $0.23-0.86)$ were as indicated. Patients who had consolidative auto-SCT had better 5 -year OS rates compared to those having chemotherapy alone ( $75 \%$ vs $41 \%$; $p=N S$ ).

Nine patients had autologous SCT following salvage treatments. Five patients responded to auto-SCT (4 CR and 1 PR). The median OS was 20 months ( $95 \% \mathrm{Cl}: 0.16$ 0.79 ), and PFS was less than 2 months ( $95 \% \mathrm{Cl}$ : 0.08 $0.62)$.

Four patients underwent allo-SCT (1 AITCL, 1 PTCL-NOS, 1 HSTCL, 1 ALK-ALCL). Two of them had previous autoSCT. Three of them died due to progressive disease $(n=1)$ and infectious complications $(n=2)$.

One patient with ALK-ALCL relapsed at the fifth year of auto-SCT. This patient achieved CR with reuse of CHOEP but experienced a second relapse and underwent alloSCT after salvage BV\&GDP treatment. He is still alive with complete response at the 115th month of followup.

\section{Risk Factors}

Progression was frequently associated with T cell-lymphomas having other than ALK+ALCL $(p=0.004)$ histology. For ALK- ALCL, advanced stage disease $(p=0.000)$, serum albumin $<3.4 \mathrm{~g} / \mathrm{dl}(\mathrm{p}=0.013)$, serum total protein $\leq 6.2 \mathrm{~g} / \mathrm{dl}(\mathrm{p}=0.032)$, high serum lactate dehydrogenase level $(L D H) \quad(p=0.042)$, serum ferritin $>200 \mathrm{ng} / \mathrm{ml}$ $(p=0.006)$, presence of $B$ symptoms $(p=0.03)$, and extranodal involvement of more than one site $(p=0.021)$ at the time of diagnosis were associated with progression. In addition, hemoglobin level less than $10 \mathrm{gr} / \mathrm{dl}$ $(p=0.061)$ and bone marrow involvement at the time of diagnosis $(p=0.103)$ tend to be more frequently-though not statistically significantly- associated with progressive disease. In the multivariate analysis, high serum LDH and extranodal involvement involving more than one organ were found to be significant. For $A L K+A L C L$, none of the risk factors was associated with progressive disease.

In the univariate analysis, $\mathrm{T}$ cell lymphoma type other than ALK+ALCL was associated with death ( $p=0.006)$. For ALK -positive group, none of our criteria was associated with poor OS.

For ALK- negative group, serum albumin $<3.4 \mathrm{~g} /$ $\mathrm{dl}(p=0.001)$, serum total protein $\leq 6.2 \mathrm{~g} / \mathrm{dl}(\mathrm{p}=0.032)$, serum ferritin $>200 \mathrm{ng} / \mathrm{ml}(p=0.031)$, bone marrow involvement $(p=0.020)$ at the time of diagnosis were associated with death. In the multivariate analysis, only bone marrow involvement was associated with poor survival. Although not statistically significant, high serum lactate dehydrogenase $(L D H)(p=0.085)$ and 
Table 2. It showes comparison of preopertive and postoperative patients' VAS. A statistically significant decline in pain control was detected in both groups.

\begin{tabular}{|c|c|c|c|c|c|c|c|c|}
\hline & $\begin{array}{c}\text { All patients } \\
(\mathrm{n}=62)\end{array}$ & $\begin{array}{c}\text { ALK+ALCL } \\
(\mathrm{n}=9)\end{array}$ & $\begin{array}{c}\text { PTCL, NOS } \\
(n=17)\end{array}$ & $\begin{array}{l}\text { AITCL } \\
(n=13)\end{array}$ & $\begin{array}{l}\text { ALK-ALCL } \\
(n=12)\end{array}$ & $\begin{array}{c}\text { Hepatosplenic T cell } \\
\text { lymphoma } \\
(n=4)\end{array}$ & $\begin{array}{l}\text { Enteropathy ass. T cell } \\
\text { lymphoma } \\
(\mathrm{n}=4)\end{array}$ & $\begin{array}{c}\mathrm{NK} / \mathrm{T} \text { cell } \\
\text { lymphoma } \\
(\mathrm{n}=3)\end{array}$ \\
\hline Age, median (range) & $54(20-82)$ & $32(20-66)$ & $62(28-73)$ & $65(30-82)$ & $52.5(24-79)$ & $58(26-64)$ & $52.5(35-58)$ & $43(32-47)$ \\
\hline Male vs Female & 46 vs 16 & 9 vs 0 & 11 vs 6 & 8 vs 5 & 8 vs 4 & 4 vs 0 & 3 vs 1 & 3 vs 0 \\
\hline $\begin{array}{l}\text { B symptoms } \\
\text { present } \\
\text { absent }\end{array}$ & $\begin{array}{l}37 \\
19\end{array}$ & $\begin{array}{l}4 \\
5\end{array}$ & $\begin{array}{c}10 \\
5\end{array}$ & $\begin{array}{l}8 \\
3 \\
\end{array}$ & $\begin{array}{l}4 \\
6\end{array}$ & $\begin{array}{l}3 \\
1\end{array}$ & $\begin{array}{l}4 \\
0\end{array}$ & $\begin{array}{l}3 \\
0\end{array}$ \\
\hline $\begin{array}{l}\text { Stage } \\
\text { I-II } \\
\text { III-IV }\end{array}$ & $\begin{array}{l}13 \\
43\end{array}$ & $\begin{array}{l}3 \\
6\end{array}$ & $\begin{array}{c}3 \\
11\end{array}$ & $\begin{array}{c}1 \\
12\end{array}$ & $\begin{array}{l}3 \\
8\end{array}$ & $\begin{array}{l}1 \\
2\end{array}$ & $\begin{array}{l}1 \\
2\end{array}$ & $\begin{array}{l}1 \\
2\end{array}$ \\
\hline $\begin{array}{l}\text { Bone marrow involvement } \\
\text { present } \\
\text { absent }\end{array}$ & $\begin{array}{l}19 \\
37\end{array}$ & $\begin{array}{l}2 \\
7\end{array}$ & $\begin{array}{l}6 \\
8\end{array}$ & $\begin{array}{l}2 \\
9\end{array}$ & $\begin{array}{l}2 \\
8\end{array}$ & $\begin{array}{l}4 \\
0\end{array}$ & $\begin{array}{l}0 \\
4\end{array}$ & $\begin{array}{l}2 \\
1\end{array}$ \\
\hline $\begin{array}{l}\text { Extranodal involvement } \\
0-1 \\
\geq 2\end{array}$ & $\begin{array}{l}37 \\
17\end{array}$ & $\begin{array}{l}8 \\
1\end{array}$ & $\begin{array}{l}8 \\
6\end{array}$ & $\begin{array}{l}9 \\
1\end{array}$ & $\begin{array}{l}7 \\
3\end{array}$ & $\begin{array}{l}2 \\
2\end{array}$ & $\begin{array}{l}2 \\
2\end{array}$ & $\begin{array}{l}1 \\
2\end{array}$ \\
\hline $\begin{array}{l}\text { ECOG Performance Score } \\
0-1 \\
\geq 2\end{array}$ & $\begin{array}{l}43 \\
18\end{array}$ & $\begin{array}{l}9 \\
0\end{array}$ & $\begin{array}{c}23 \\
5\end{array}$ & $\begin{array}{c}20 \\
3\end{array}$ & $\begin{array}{l}5 \\
6\end{array}$ & $\begin{array}{l}2 \\
2\end{array}$ & $\begin{array}{l}2 \\
2\end{array}$ & $\begin{array}{l}2 \\
1\end{array}$ \\
\hline $\begin{array}{l}\text { Serum LDH } \\
\text { Normal } \\
>\text { ULN }\end{array}$ & $\begin{array}{l}18 \\
29\end{array}$ & $\begin{array}{l}6 \\
3\end{array}$ & $\begin{array}{l}7 \\
8\end{array}$ & $\begin{array}{l}7 \\
6\end{array}$ & $\begin{array}{l}6 \\
4\end{array}$ & $\begin{array}{l}0 \\
4\end{array}$ & $\begin{array}{l}2 \\
1\end{array}$ & $\begin{array}{l}1 \\
2\end{array}$ \\
\hline $\begin{array}{l}\text { Serum albumin } \\
<3.4 \mathrm{~g} / \mathrm{dl} \\
\geq 3.4 \mathrm{~g} / \mathrm{dl}\end{array}$ & $\begin{array}{l}23 \\
28\end{array}$ & $\begin{array}{l}3 \\
6\end{array}$ & $\begin{array}{l}5 \\
8\end{array}$ & $\begin{array}{l}7 \\
4\end{array}$ & $\begin{array}{l}4 \\
5\end{array}$ & $\begin{array}{l}2 \\
2\end{array}$ & $\begin{array}{l}1 \\
2\end{array}$ & $\begin{array}{l}1 \\
1\end{array}$ \\
\hline $\begin{array}{l}\text { Serum total protein } \\
\leq 6.2 \mathrm{~g} / \mathrm{dl} \\
>6.2 \mathrm{~g} / \mathrm{dl}\end{array}$ & $\begin{array}{l}17 \\
26\end{array}$ & $\begin{array}{l}1 \\
8\end{array}$ & $\begin{array}{l}2 \\
7\end{array}$ & $\begin{array}{l}7 \\
3\end{array}$ & $\begin{array}{l}2 \\
6\end{array}$ & $\begin{array}{l}1 \\
2\end{array}$ & 3 & $\begin{array}{l}1 \\
1\end{array}$ \\
\hline $\begin{array}{l}\text { Serum ferritin } \\
<200 \mathrm{ng} / \mathrm{ml} \\
\geq 200 \mathrm{ng} / \mathrm{ml}\end{array}$ & $\begin{array}{c}9 \\
29\end{array}$ & $\begin{array}{l}1 \\
6\end{array}$ & $\begin{array}{l}2 \\
7\end{array}$ & $\begin{array}{l}2 \\
6\end{array}$ & $\begin{array}{l}2 \\
5\end{array}$ & 1 & 3 & $\begin{array}{l}1 \\
2\end{array}$ \\
\hline $\begin{array}{l}\text { Hemoglobin } \\
<10 \mathrm{~g} / \mathrm{dl} \\
\geq 10 \mathrm{~g} / \mathrm{dl}\end{array}$ & $\begin{array}{l}20 \\
36\end{array}$ & $\begin{array}{l}1 \\
8\end{array}$ & $\begin{array}{l}5 \\
8\end{array}$ & $\begin{array}{c}5 \\
10\end{array}$ & $\begin{array}{l}3 \\
7\end{array}$ & $\begin{array}{l}3 \\
1\end{array}$ & $\begin{array}{l}2 \\
1\end{array}$ & $\begin{array}{l}1 \\
2\end{array}$ \\
\hline $\begin{array}{l}\text { Platelets } \\
\geq 150.000 / \mathrm{mm}^{3} \\
<150.000 / \mathrm{mm}^{3}\end{array}$ & $\begin{array}{l}40 \\
16\end{array}$ & $\begin{array}{l}8 \\
0\end{array}$ & $\begin{array}{l}9 \\
6\end{array}$ & $\begin{array}{c}11 \\
2\end{array}$ & $\begin{array}{l}7 \\
3\end{array}$ & $\begin{array}{l}2 \\
2\end{array}$ & $\begin{array}{l}2 \\
1\end{array}$ & $\begin{array}{l}1 \\
2\end{array}$ \\
\hline $\begin{array}{l}\text { Absolute neutrophil count } \\
\leq 6500 / \mathrm{mm}^{3} \\
>6500 / \mathrm{mm}^{3}\end{array}$ & $\begin{array}{l}36 \\
19\end{array}$ & $\begin{array}{l}3 \\
5\end{array}$ & $\begin{array}{c}1 \\
14\end{array}$ & $\begin{array}{l}5 \\
8\end{array}$ & $\begin{array}{l}5 \\
5\end{array}$ & $\begin{array}{l}3 \\
0\end{array}$ & $\begin{array}{l}1 \\
2\end{array}$ & $\begin{array}{l}2 \\
1\end{array}$ \\
\hline $\begin{array}{l}\text { Response to first line treatment available } \\
\text { for } \\
\text { Complete response } \\
\text { Partial response } \\
\text { Stable disease } \\
\text { Progressive disease }\end{array}$ & $\begin{array}{c}\mathrm{n}=57 \\
23 \\
7 \\
2 \\
25\end{array}$ & $\begin{array}{c}\mathrm{n}=8 \\
7 \\
0 \\
0 \\
1\end{array}$ & $\begin{array}{c}\mathrm{n}=16 \\
5 \\
3 \\
1 \\
7\end{array}$ & $\begin{array}{c}\mathrm{n}=13 \\
3 \\
1 \\
1 \\
8\end{array}$ & $\begin{array}{c}\mathrm{n}=12 \\
6 \\
2 \\
0 \\
4\end{array}$ & $\begin{array}{l}c \\
0 \\
1 \\
0 \\
2\end{array}$ & $\begin{array}{c}\mathrm{n}=\mathbf{3} \\
2 \\
0 \\
0 \\
1\end{array}$ & $\begin{array}{c}\mathrm{n}=\mathbf{2} \\
0 \\
0 \\
0 \\
2\end{array}$ \\
\hline $\begin{array}{l}\text { IPI Score available for } \\
0 \& 1 \\
2 \& 3 \\
4 \& 5\end{array}$ & $\begin{array}{c}n=55 \\
19 \\
28 \\
9\end{array}$ & $\begin{array}{c}\mathrm{n}=9 \\
6 \\
2 \\
1\end{array}$ & $\begin{array}{c}\mathrm{n}=13 \\
5 \\
5 \\
3\end{array}$ & $\begin{array}{c}\mathrm{n}=13 \\
3 \\
9 \\
1\end{array}$ & $\begin{array}{c}\mathrm{n}=11 \\
3 \\
6 \\
2\end{array}$ & $\begin{array}{c}\mathrm{n}=4 \\
0 \\
3 \\
1\end{array}$ & $\begin{array}{c}\mathrm{n}=3 \\
1 \\
1 \\
1\end{array}$ & $\begin{array}{c}\mathrm{n}=3 \\
1 \\
2 \\
0\end{array}$ \\
\hline $\begin{array}{l}\text { NCCN-IPI Score available for } \\
0 \& 1 \\
2 \& 3 \\
4 \& 5 \\
\geq 6\end{array}$ & $\begin{array}{c}\mathrm{n}=56 \\
5 \\
26 \\
22 \\
3\end{array}$ & $\begin{array}{c}\mathrm{n}=9 \\
1 \\
8 \\
0 \\
0\end{array}$ & $\begin{array}{c}\mathrm{n}=\mathbf{1 3} \\
1 \\
5 \\
5 \\
2\end{array}$ & $\begin{array}{c}\mathrm{n}=13 \\
1 \\
5 \\
7 \\
0\end{array}$ & $\begin{array}{c}\mathrm{n}=11 \\
1 \\
5 \\
4 \\
1\end{array}$ & $\begin{array}{c}\mathrm{n}=4 \\
1 \\
3 \\
0 \\
0\end{array}$ & $\begin{array}{c}\mathrm{n}=\mathbf{3} \\
1 \\
1 \\
1 \\
0\end{array}$ & $\begin{array}{c}\mathrm{n}=\mathbf{3} \\
1 \\
2 \\
0 \\
0\end{array}$ \\
\hline $\begin{array}{l}\text { PIT score available for } \\
0 \\
1 \\
2 \\
3 \& 4\end{array}$ & $\begin{array}{c}\mathrm{n}=\mathbf{5 3} \\
13 \\
15 \\
13 \\
12\end{array}$ & $\begin{array}{c}\mathrm{n}=9 \\
4 \\
4 \\
0 \\
1\end{array}$ & $\begin{array}{c}\mathrm{n}=14 \\
3 \\
5 \\
2 \\
4\end{array}$ & $\begin{array}{c}\mathrm{n}=11 \\
2 \\
2 \\
6 \\
1\end{array}$ & $\begin{array}{c}\mathrm{n}=\mathbf{9} \\
2 \\
3 \\
2 \\
2\end{array}$ & $\begin{array}{c}\mathrm{n}=4 \\
0 \\
0 \\
1 \\
3\end{array}$ & $\begin{array}{c}\mathrm{n}=\mathbf{3} \\
1 \\
1 \\
1 \\
0\end{array}$ & $\begin{array}{c}\mathrm{n}=\mathbf{3} \\
1 \\
0 \\
1 \\
1\end{array}$ \\
\hline $\begin{array}{l}\text { ITCLP score available for } \\
0 \\
1 \\
2 \\
3\end{array}$ & $\begin{array}{c}n=56 \\
20 \\
22 \\
12 \\
3\end{array}$ & $\begin{array}{c}\mathrm{n}=8 \\
7 \\
1 \\
0 \\
0\end{array}$ & $\begin{array}{c}\mathrm{n}=16 \\
5 \\
6 \\
4 \\
1\end{array}$ & $\begin{array}{c}\mathrm{n}=13 \\
4 \\
6 \\
2 \\
1\end{array}$ & $\begin{array}{c}\mathrm{n}=10 \\
2 \\
4 \\
4 \\
0\end{array}$ & $\begin{array}{c}\mathrm{n}=4 \\
1 \\
1 \\
1 \\
1\end{array}$ & $\begin{array}{c}\mathrm{n}=\mathbf{3} \\
0 \\
3 \\
0 \\
0\end{array}$ & $\begin{array}{c}\mathrm{n}=\mathbf{3} \\
1 \\
1 \\
1 \\
0\end{array}$ \\
\hline $\begin{array}{l}\text { T cell score available for } \\
0 \\
1 \& 2 \\
3 \& 4\end{array}$ & $\begin{array}{c}\mathrm{n}=53 \\
3 \\
36 \\
14\end{array}$ & $\begin{array}{c}\mathrm{n}=9 \\
1 \\
7 \\
1\end{array}$ & $\begin{array}{c}\mathrm{n}=12 \\
1 \\
8 \\
3\end{array}$ & $\begin{array}{c}\mathrm{n}=13 \\
0 \\
9 \\
2\end{array}$ & $\begin{array}{c}\mathrm{n}=10 \\
2 \\
7 \\
1\end{array}$ & $\begin{array}{c}\mathrm{n}=3 \\
1 \\
2 \\
0\end{array}$ & $\begin{array}{c}\mathrm{n}=3 \\
0 \\
2 \\
1\end{array}$ & $\begin{array}{c}\mathrm{n}=3 \\
0 \\
2 \\
1\end{array}$ \\
\hline
\end{tabular}


presence of B symptoms ( $p=0.066)$ were more frequently detected in patients with poor OS.

As expected, response to first- line treatment was statistically significantly associated with decreased progression $(p=0.000)$ and death $(p=0.000)$ rates. The International Prognostic Index (IPI) $(p=0.007)$, the National Comprehensive Cancer Network (NCCN)-IPI $(p=0.03)$ were effective in discriminating progressive cases in ALK- negative, but not in ALK- positive group. The NCCN-IPI $(p=0.035)$ was effective to predict deaths in ALK- negative group.

\section{Deaths\& Secondary Malignancies}

Forty-one patients (66\%) died during the follow-up period. Most common etiologies were progressive disease and infections.

Four patients developed secondary malignancies including esophageal squamous cell cancer in $1 \mathrm{EATCL}$; myelodysplastic syndrome in $1 \mathrm{HSTCL} 1 \mathrm{HL}$ in $1 \mathrm{PTCL}$ and multiple myeloma in 1 PTCL patient. None of them had radiotherapy history and the median follow-up time was 73 months (range: 27-156 months).

\section{DISCUSSION}

PTCLs are less responsive to conventional anthracycline- based regimens. Savage et al. reported that the ORR with anthracycline-based treatment was $73 \%$ for PTCL, with 3-year PFS and OS rates of $32 \%$ and $52 \%$, respectively. Compared to ALK- negative PTCLs, ALKpositive group was reported to have better 5-year FFS (60\% vs $36 \%, p=0.015)$ and OS ( $70 \%$ vs $46 \%, p=0.016$ ) rates ${ }^{(3)}$. In the Japanese experience, 5-year PFS and OS rates for PTCL-NOS were $28 \%$ and $35 \%$, respectively. The 5 -year OS rate was almost $60 \%$ for patients consolidated with auto-SCT (20).With a median OS of 1.59 years, the 4 -year OS rate was $34 \%$ in the Australian cohort ${ }^{(21)}$. In our cohort, the ORR to the first- line treatment was $52 \%$. Five-year PFS, and OS rates were $19 \%$, and $26 \%$, respectively. Five-year PFS rates were $66 \%$ and $19 \%$ for ALK+ALCL and non-ALK+ groups, respectively. Similarly, 5 -year OS rate was $75 \%$ for ALK+ALCL group and $18 \%$ for the rest of the cohort.

The place for SCT as consolidation treatment is for PTCLs still debatable. Reimer et al reported that $66 \%$ of PTCL patients were able to proceed to SCT consolidation. All 55 patients kept their response following transplantation and the 3-year OS and PFS rates were $48 \%$ and $36 \%$, respectively ${ }^{(22)}$. CHOEP followed by high dose therapy and SCT was reported to be effective for ALKnegative PTCL patients, with 5-year PFS and OS rates of $44 \%$ and $51 \%$, respectively ${ }^{(23)}$. Better OS rates were also reported in a Japanese cohort ${ }^{(20)}$. In our cohort, patients who had consolidative auto-SCT had better OS rates ( $75 \%$ vs $41 \%$; $p=N S$ ). On the other hand, auto-SCT following salvage treatment did not improve the outcome.

To predict the prognosis in PTCLs, variable risk factors were defined elsewhere ${ }^{(6-10)}$ and many efforts were made for amelioration ${ }^{(20,21,24)}$. In our study, there were no risk factor associated with OS and PFS in ALK+ ALCL patients. For ALK- negative group, IPI ${ }^{(1)}$, NCCN-IPI ${ }^{(10)}$ scores were able to discriminate risk groups to predict PFS and, NCCN-IPI was able to discriminate risk groups to predict OS. We, with this study observed that high stage disease, serum albumin $<3.4 \mathrm{~g} / \mathrm{dl}$, serum total protein $\leq 6.2 \mathrm{~g} / \mathrm{dl}$, high serum $\mathrm{LDH}$, serum ferritin $>200$ $\mathrm{ng} / \mathrm{ml}$, presence of $\mathrm{B}$ symptoms, and extranodal involvement of more than one site at the time of diagnosis were associated with disease progression in ALK -negative patients in the univariate analysis. Serum albumin $<3.4 \mathrm{~g} / \mathrm{dl}$, serum total protein $\leq 6.2 \mathrm{~g} / \mathrm{dl}$, serum ferritin $>200 \mathrm{ng} / \mathrm{ml}$, bone marrow involvement at the time of diagnosis were associated with death. In the multivariate analysis, high serum LDH and extranodal involvement of more than one organ were found to be significant to predict progression, whereas only bone marrow involvement was associated with death.

Our study showed a secondary malignancy risk which is not a well-known entity for PTCL. Thus, in patients with extended follow-up, evolving secondary malignancies should be kept in mind.

One of our patients was initially diagnosed as having $\mathrm{HL}$ however, PTCL-NOS was defined in the re-evaluation emphasizing the still challenging complexity of the PTCLs.

The survival rates in our study were lower compared to literature, which may be due to exclusion of 'untreated' patients in the majority of the studies. Our study is a reflection of the 'real-life'. The experience with 3 patients, who died due to disease progression after diagnosis without receiving treatment, point out aggressiveness of the disease and we observed also CHOP- based regimen for PTCLs other than ALK- positive ALCLs needs to be replaced by another treatment modality. Although the low number of patients is a 
limitation of our study, it is a single- center study and PTCLs are rare types among NHLs.

A recently published study has suggested that patients receiving novel agents have superior outcomes compared to cases who received chemotherapy-based treatments ${ }^{(25)}$. However, newer agents are still being searched for the optimal treatment to be given. Although DUSP22 was defined as a favorable prognostic factor for ALK- negative group ${ }^{(11)}$, advances in molecular research could not still compare this group to other types of NHL, which may be seen in scarce number of PTCL patients and multi-center comprehensive organizations should be realized. More effective prognostic indices are needed to better stratify PTCL patients, to define the subgroup which might have advantage of SCT consolidation so as to be able to suppress the disease early in its nature.

Ethics Committee Approval: Istanbul University Istanbul Medical Faculty Ethics Committee (2019/1044), Conflict of Interest: No conflict of interest was declared by the authors.

Funding: No funding was used for this study.

Informed Consent: Informed consent was taken from all the participants.

\section{REFERENCES}

1. Langner S, Henker C. Vertebroplasty and kyphoplasty: A critical statement. Radiologe. 2020;60(2):138-43. https://doi.org/10.1007/s00117-020-00651-z

2. McGraw JK, Lippert JA, Minkus KD, et al. Prospective evaluation of pain relief in 100 patients undergoing percutaneous vertebroplasty: results and follow-up. J Vasc Interv Radiol. 2002;13:883-6. https://doi.org/10.1016/S1051-0443(07)61770-9

3. Amar AP, Larsen DW, Esnaashari N, et al. Percutaneous transpedicular polymethylmethacrylate vertebroplasty for the treatment of spinal compression fractures. Neurosurgery. 2001; 49:1105-14; discussion 1114-5. PMID: 11846904. https://doi.org/10.1227/00006123-200111000-00017

4. Galibert $P$, Deramond $H$, Rosat $P$, et al. Preliminary note on the treatment of vertebral angioma by percutaneous acrylic vertebroplasty. Neurochirurgie. 1987; 33:166-8. PMID: 3600949

5. Tang J, Guo WC, Hu JF, et al. Unilateral and Bilateral Percutaneous Kyphoplasty for Thoracolumbar Osteoporotic Compression Fractures. I Coll Physicians Surg Pak. 2019;29(10):946-50.

https://doi.org/10.29271/jcpsp.2019.10.946

6. Liebschner MA, Rosenberg WS, Keaveny TM. Effects of bone cement volume and distribution on vertebral stiffness after vertebroplasty. Spine (Phila Pa 1976). 2001;26(14):1547-54. https://doi.org/10.1097/00007632-200107150-00009

7. Deng $X Q, W u Y S$, Wang HM. Application of contralateral supplementary puncture in unilateral percutaneous vertebroplasty for poor bone cement dispersion. Zhongguo Gu Shang. 2018;31:1168-71.

https://doi.org/10.3969/j.issn.1003-0034.2018.12.019

8. Sun HB, Hai Y. In Reply to "Does Optimal Volume Fraction in Percutaneous Vertebroplasty Prevent Cement Leakage?".
World Neurosurg. 2018;116:491.

https://doi.org/10.1016/j.wneu.2018.05.076

9. Kwon HM, Lee SP, Baek JW, Kim SH. Appropriate Cement Volume in Vertebroplasty: A Multivariate Analysis with ShortTerm Follow-Up. Korean J Neurotrauma. 2016;12(2):128-34. https://doi.org/10.13004/kjnt.2016.12.2.128

10. Kaufmann TJ, Trout AT, Kallmes DF. The effects of cement volume on clinical outcomes of percutaneous vertebroplasty. AJNR Am J Neuroradiol. 2006;27:1933-7. PMID: 17032870

11. Gstottner M, Angerer A, Rosiek R, Bach CM. Quantitative volumetry of cement leakage in viscosity-controlled vertebroplasty. J Spinal Disord Tech. 2012;25(5):E150-4. https://doi.org/10.1097/BSD.0b013e31823f62b1

12. Sun $H B$, Jing $X S$, Liu YZ, Qi M, Wang XK, Hai Y. The optimal volume fraction in percutaneous vertebroplasty evaluated by pain relief, cement dispersion, and cement leakage: a prospective cohort study of 130 patients with painful osteoporotic vertebral compression fracture in the thoracolumbar vertebra. World Neurosurg. 2018;114:e677-e688. https://doi.org/10.1016/j.wneu.2018.03.050

13. McKiernan F, Faciszewski T, Jensen R. Quality of life following vertebroplasty. J Bone Joint Surg Am. 2004;86:2600-6. https://doi.org/10.2106/00004623-200412000-00003

14. Yang EZ, Xu JG, Huang GZ, et al. Percutaneous Vertebroplasty versus Conservative Treatment in Aged Patients with Acute Osteoporotic Vertebral Compression Fractures: A Prospective Randomized Controlled Clinical Study. Spine (Phila Pa 1976). 2016;41(8):653-60. https://doi.org/10.1097/BRS.0000000000001298

15. Wang B, Guo H, Yuan L et al. A prospective randomized controlled study comparing the pain relief in patients with osteoporotic vertebral compression fractures with the use of vertebroplasty or facet blocking. Eur Spine J. 2016;25(11):3486-94. https://doi.org/10.1007/s00586-016-4425-4

16. Silverman SL, Minshall ME, Shen W, et al. The relationship of health-related quality of life to prevalent and incident vertebral fractures in postmenopausal women with osteoporosis: results from the Multiple Outcomes of Raloxifene Evaluation Study. Arthritis Rheum. 2001;44(11):2611-9.

h t t p s: / / d o i.org / $10.1002 / 1529$. 0131(200111)44:11<2611::AID-ART441>3.0.CO;2-N

17. Wong W. Vertebroplasty/kyphoplasty. J Womens Imaging. 2000;2:117-24.

18. Zhang L, Zhai P. A Comparison of Percutaneous Vertebroplasty versus Conservative Treatment in Terms of Treatment Effect for Osteoporotic Vertebral Compression Fractures: A MetaAnalysis. Surg Innov. 2020;27(1):19-25. https://doi.org/10.1177/1553350619869535

19. Theodorou DJ, Theodorou SJ, Duncan TD, et al. Percutaneous balloon kyphoplasty for the correction of spinal deformity in painful vertebral body compression fractures. Clin Imaging. 2002;26:1-5. https://doi.org/10.1016/S0899-7071(01)00350-3

20. Yang $\mathrm{W}$, Song J, Liang $\mathrm{M}$, et al. Functional Outcomes and New Vertebral Fractures in Percutaneous Vertebroplasty and Conservative Treatment of Acute Symptomatic Osteoporotic Vertebral Compression Fractures. World Neurosurg. 2019;131 e346-e352. https://doi.org/10.1016/j.wneu.2019.07.153

21. Perez-Higueras A, Alvarez L, Rossi RE, et al. Percutaneous vertebroplasty: long-term clinical and radiological outcome. Neuroradiology. 2002;44:950-4. https://doi.org/10.1007/s00234-002-0856-1

22. D'Errico S, Niballi S, Bonuccelli D. Fatal cardiac perforation and pulmonary embolism of leaked cement after percutaneous vertebroplasty. J Forensic Leg Med. 2019;63:48-51. https://doi.org/10.1016/j.jflm.2019.03.004

23. Hsieh MK, Kao FC, Chiu PY, et al. Risk factors of neurological deficit and pulmonary cement embolism after percutaneous vertebroplasty. J Orthop Surg Res. 2019;14:406. https://doi.org/10.1186/s13018-019-1459-4 